\title{
SLC54 Mitochondrial pyruvate carriers (version 2020.5) in the IUPHAR/BPS Guide to Pharmacology Database
}

\author{
Calum Wilson ${ }^{1}$ \\ 1. University of Strathclyde, UK
}

\begin{abstract}
Pyruvate is oxidized to acetyl-CoA by pyruvate dehydrogenase which is localized in the mitochondrial matrix. The mitochondrial pyruvate carrier (MPC) is a hetero-oligomer composed of SLC54 family members (MPC1 and MPC2). The MPC is expressed in the inner mitochondrial membrane and involved in the import of pyruvate into mitochondria [1,5]. Ubiquitous disruption of either MPC1 or MPC2 expression results in embryonic lethality 7 , 8]. Clinically relevant concentrations of the insulin sensitizers, thiazolidinediones, specifically inhibit the MPC B].
\end{abstract}

\section{Contents}

This is a citation summary for SLC54 Mitochondrial pyruvate carriers in the Guide to Pharmacology database (GtoPdb). It exists purely as an adjunct to the database to facilitate the recognition of citations to and from the database by citation analyzers. Readers will almost certainly want to visit the relevant sections of the database which are given here under database links.

GtoPdb is an expert-driven guide to pharmacological targets and the substances that act on them. GtoPdb is a reference work which is most usefully represented as an on-line database. As in any publication this work should be appropriately cited, and the papers it cites should also be recognized. This document provides a citation for the relevant parts of the database, and also provides a reference list for the research cited by those parts.

Please note that the database version for the citations given in GtoPdb are to the most recent preceding version in which the family or its subfamilies and targets were substantially changed. The links below are to the current version. If you need to consult the cited version, rather than the most recent version, please contact the GtoPdb curators.

\section{Database links}

SLC54 Mitochondrial pyruvate carriers

https://www.guidetopharmacology.org/GRAC/FamilyDisplayForward?familyld=1006

Transporters

mitochondrial pyruvate carrier 1

https://www.guidetopharmacology.org/GRAC/ObjectDisplayForward?objectld=3022

mitochondrial pyruvate carrier 2

https://www.guidetopharmacology.org/GRAC/ObjectDisplayForward?objectld=3023

mitochondrial pyruvate carrier 1 like

https://www.guidetopharmacology.org/GRAC/ObjectDisplayForward?objectld=3024

\section{References}

1. Bricker DK, Taylor EB, Schell JC, Orsak T, Boutron A, Chen YC, Cox JE, Cardon CM, Van Vranken JG and Dephoure $\mathrm{N}$ et al.. (2012) A mitochondrial pyruvate carrier required for pyruvate uptake in yeast, Drosophila, and humans. Science 337: 96-100 [PMID:22628558]

2. Colca JR, McDonald WG, Cavey GS, Cole SL, Holewa DD, Brightwell-Conrad AS, Wolfe CL, Wheeler JS, Coulter KR and Kilkuskie PM et al.. (2013) Identification of a mitochondrial target of thiazolidinedione insulin sensitizers (mTOT)--relationship to newly identified mitochondrial pyruvate carrier proteins. PLoS One 8: e61551 [PMID:23690925]

3. Divakaruni AS, Wiley SE, Rogers GW, Andreyev AY, Petrosyan S, Loviscach M, Wall EA, Yadava N, Heuck AP and Ferrick DA et al.. (2013) Thiazolidinediones are acute, specific inhibitors of the mitochondrial pyruvate carrier. Proc Natl Acad Sci U S A110: 5422-7 [PMID:23513224] 
4. Halestrap AP. (1975) The mitochondrial pyruvate carrier. Kinetics and specificity for substrates and inhibitors. Biochem J 148: 85-96 [PMID:1156402]

5. Herzig S, Raemy E, Montessuit S, Veuthey JL, Zamboni N, Westermann B, Kunji ER and Martinou JC. (2012) Identification and functional expression of the mitochondrial pyruvate carrier. Science 337: 93-6 [PMID:22628554]

6. Vanderperre B, Cermakova K, Escoffier J, Kaba M, Bender T, Nef S and Martinou JC. (2016) MPC1-like Is a Placental Mammal-specific Mitochondrial Pyruvate Carrier Subunit Expressed in Postmeiotic Male Germ Cells. J. Biol. Chem. 291: 16448-61 [PMID:27317664]

7. Vanderperre B, Herzig S, Krznar P, Hörl M, Ammar Z, Montessuit S, Pierredon S, Zamboni N and Martinou JC. (2016) Embryonic Lethality of Mitochondrial Pyruvate Carrier 1 Deficient Mouse Can Be Rescued by a Ketogenic Diet. PLoS Genet 12: e1006056 [PMID:27176894]

8. Vigueira PA, McCommis KS, Schweitzer GG, Remedi MS, Chambers KT, Fu X, McDonald WG, Cole SL, Colca JR and Kletzien RF et al.. (2014) Mitochondrial pyruvate carrier 2 hypomorphism in mice leads to defects in glucose-stimulated insulin secretion. Cell Rep 7: 2042-2053 [PMID:24910426] 